\title{
Insentif PMK 86/2020 Di Tengah Pandemi Covid 19: Apakah Mempengaruhi Kepatuhan Wajib Pajak UMKM Di Surabaya?
}

\author{
Richard Andrew ${ }^{1)}$, Dian Purnama Sari ${ }^{2)}$ \\ ${ }^{1,2}$ Pascasarjana Akuntansi, Universitas Katolik Widya Mandala Surabaya \\ *Email korespondensi: andrew_richard1@yahoo.com
}

\begin{abstract}
This study describes researchTaxpayer Compliance in the Covid-19 pandemic. The purpose was to analyze and determine effects of socialization PMK 86/2020 incentives, tax rates, tax services, PP 23/2018 deadline, and tax punishmentforMSME taxpayer compliance in Surabaya. The method in the research is quantitative by testing hypothesis. Data obtained through any questions and distributed via google form to all taxpayers (MSMEs) in the Surabaya.The results showed that variable of PMK 86/2020 incentive socialization, tax rates, tax services, deadline of PP 23/2018 has effects, while tax punishment hasn't effect for MSME taxpayer compliance. The Conclusions are socialization of PMK 86/2020 incentives has been carried out by the government massively andthey raises knowledge to immediately take advantage of incentives. They will to take advantage of lower tax rates during pandemic. The change in services from face-to-face to 100\% online makes them easier to know information, procedures for compliance and keep health protocols in the pandemic. Deadline for PP 23/2018 supports them to understand how to bookkeeping until limit is given and utilization of determined rates. Tax punishment hasn't effect because it's not too strict during the pandemic and tend to be loose and various relaxation provided by the government.
\end{abstract}

Keywords: Micro, Small and Medium Enterprises (MSMEs) Taxpayers Compliance in Surabaya, PMK 86/2020 Incentive Socialization, Tax Rates and Fiscal Services, PP 23/2018 Deadline, Tax Punishment.

Saran sitasi: Andrew, R., \& Sari, D. P. (2021). Insentif PMK 86/2020 Di Tengah Pandemi Covid 19: Apakah Mempengaruhi Kepatuhan Wajib Pajak UMKM Di Surabaya?. Jurnal Akuntansi dan Pajak, 21 (2), 349-366. doi:http://dx.doi.org/10.29040/jap.v21i2.1597

DOI: http://dx.doi.org/10.29040/jap.v21i2.1597

\section{PENDAHULUAN}

Pada tahun 2020 seluruh negara mengalami krisis ekonomi dikarenakan suatu wabah yang dikenal dengan Corona Virus Disease (Covid-19), semua negara mengalami penurunan ekonomi secara drastis dan tentunya berdampak di negara kita Indonesia baik secara makro ekonomi maupun mikro ekonomi. Secara mikro ekonomi, wabah Covid-19 berdampak terhadap semua Usaha Mikro Kecil Menengah (UMKM) yang menjadi penopang perkembangan ekonomi Indonesia, banyak usaha UMKM di Indonesia mengalami penurunan omset penghasilan bahkan sampai menutup usahanya dikarenakan kebangkrutan. Direktorat Jenderal Pajak telah membuat kebijakan-kebijakan perpajakan untuk mengantisipasi dampak dari Covid-19 untuk stabilitas ekonomi dan mempertahankan kepatuhan wajib pajak UMKM ditengah pandemi,dengan menerbitkan
Peraturan Menteri Keuangan nomor86/2020.Didalam PMK86/2020 ini,berisi mengenai pemberian insentif pajak bagi wajib pajak yang terdampak pandemi Corona Virus Disease (Covid-19). PMK ini juga merupakan perubahan dari PMK 44/2020 yang telah diterbitkan sebelumnya. Insentif pajak yang diberikan pemerintah dalam PMK 86/2020 meliputi PPh pasal 21,22,23, dan 25. Pemerintah memprediksi dengan adanya insentif pajak yang diberikan dapat digunakan sebagai penyelamatan ekonomi bagi UMKM yang terdampak pandemi, sehingga diharapkan UMKM tersebut mampu bertahan di tahun 2020.

Pemerintah memprioritaskan sektor UMKM untuk mampu bertahan ditengah pandemi Covid 19 ini, mengingat banyaknya tenaga kerja di dalam UMKM yang nantinya akan di PHK secara masal akibat kesulitan ekonomi, dan pemerintah tidak mengharapkan hal itu terjadi. Insentif pajak PMK 
86/2020 bagi UMKM yang diberikan pemerintah berupa PPh Final Usaha Mikro Kecil Menengah (UMKM) akan ditanggung oleh pemerintah selama enam bulan, dengan begitu wajib pajak UMKM tidak perlu membayar pajak $0,5 \%$ dari omset namun tarif menjadi $0 \%$. Syarat wajib pajak UMKM yang dapat menerimannya adalah wajib pajak UMKM harus melakukan penyampaian laporan realisasi untuk memanfaatkan pajak penghasilan final yang ditanggung oleh pemerintah paling lambat tanggal 20setelah akhir masa pajak dan berakhir sampai Desember 2020.Menurut Ayu (2020) menjelaskan bahwa insentif pajak adalah kebijakan perpajakan yang diberikan oleh pemerintah kepada wajib pajak tertentu baik individu atauorganisasi yang mendukung pemerintah, yang digunakan dalam memberikan dorongan dan kemudahan bagi wajib pajak agar tetap patuh dalam menjalankan kewajiban perpajakannya baik sekarang maupun di masa mendatang. Pemerintah selama ini telah melakukan sosialisasi mengenai insentif pajak baik melalui media cetak maupun online mengenai kebijakan-kebijakan insentif pajak diantaranya PP 46/2013,PP 23/2018, $\operatorname{tax}$ holiday,tax allowance,revaluasi asset untuk tujuan perpajakan ditahun 2015 dan 2016dan masih banyak lagi insentif yang telah diberikan kepada wajib pajak selama ini. Menurut Direktorat Jenderal Pajak (2020) menjelaskan bahwa pemerintah sampai sekarang tengah menggalakkan sosialisasi perpajakan mengenai PMK 86/2020 kepada wajib pajak UMKM dikarenakan realisasinya tidak mencapai $10 \%$ di bulan Juli 2020. Berdasarkan penelitian terdahulu yang telah dilakukan oleh Putri dan Iqbal (2019), menjelaskan bahwa ada perbedaan signifikan pada kepatuhan wajib pajak UMKM dari sebelum dan sesudah pemberian insentif pajak pemerintah PP nomor 23 tahun 2018 dari pendaftaran diri, pembayaran pajak hingga pelaporan SPT. Menurut Hardianti dan Setyowati (2018) menjelaskan bahwa kebijakan insentif tax allowance di sektor perikanan kurang efektif, peran KKP dalam melakukan sosialisasi sangat diperlukan agar implementasinya bagi wajib pajak dapat berjalan efektif.

Menurut Direktorat Jenderal Pajak (2019) menjelaskan bahwa tarif pajak adalah nilai yang menjadi dasar pengenaan pajak dan menjadi penentu pajak yang harus dibayar oleh wajib pajak mengenai objek pajak dan dinyatakan dalam persentase tertentu. Kebijakan PP 23/2018 ini pertama kali berlaku pada 1 Juli 2018 menggantikan PP 46/2013 dengan tingkat tarif yang semula $1 \%$ menjadi $0,5 \%$ atas omset penghasilannya. Dengan adanya Covid-19 ini, menyebabkan pemerintah melalui PMK 86/2020 menurunkan tarif dari semula $0,5 \%$ menjadi $0 \%$ sampai bulan Desember 2020 bagi mereka yang memanfaatkan insentif pajak, dengan maksud agar wajib pajak pelaku usaha UMKM dapat menjalankan kewajiban perpajakan semestinya.Namun yang menjadi masalah, apakah dengan kebijakan penurunan tarif tersebut menjadi $0 \%$ tetap dapat terus berpengaruh dalam pertahanan tingkat kepatuhan wajib pajak UMKM. Berdasarkan penelitian terdahulu yang dilakukan Lazuardini,dkk(2018),menjelaskan bahwa tariff pajak memiliki pengaruh positif dan signifikan terhadap ketaatan wajib pajak orang pribadi di Kantor Pelayanan Pajak Pratama Malang Selatan.

Berdasarkan Peraturan Menteri Keuangan Nomor 234/PMK.01/2015menjelaskan fungsi dari Direktorat Jenderal Pajak (fiskus) dintaranya merumuskan, dan melaksanakan kebijakan-kebijakan perpajakan, menyusun norma, standar, criteria dan prosedur-prosedur di bidang perpajakan, memberikan bimbingan secara teknis kepada wajib pajak serta memberikan evaluasi perpajakan dan memberikan pelayanan secara administrasi kepada wajib pajak.Pemerintah selama ini telah menjalankan layanan perpajakan baik secara tatap muka maupun daring/online misalnya saja pelayanan $e$-filling pajak dengan adanya layanan ini pelaporan bagi wajib pajak baik SPT1770,1770SS,1770S,dan1771sehingga memudahkan bagi wajib pajak dalam menjalankan kewajiban perpajakannya selama ini. Dengan adanya Covid-19 ini, tentu berdampak pada pelayanan perpajakan yang semula bisa dilakukan secara tatap muka sekarang menerapkan social distancing, ada pergantian kebijakan menjadi pelayanan perpajakan untuk memenuhi protokol kesehatan yaitu 100\% secara daring/online melalui akses online https://www.pajak.go.id/covid19. Hal itu berarti dalam pendaftaran NPWP, pelaporan SPT, permintaan surat keterangan fiskal dan pembayaran pajak semua menggunakan media online. Penelitian yang telah dilakukan oleh Tambunan (2016), menjelaskan pelayanan dari KPP memiliki pengaruh signifikan terhadap kepatuhan wajib pajak pelaku usaha UKM sebesar 21,8\%. Dengan peralihandari pelayanan tatap muka menjadi media online atau daring $100 \%$, apakah memudahkan wajib pajak Usaha Mikro Kecil Menengah (UMKM) dalam memenuhi kewajiban perpajakannya dalam pelaporan dan 
pembayaran pajak atas penghasilannya. Mengingat adanya ketidaktahuan cara pengoperasian dan beban biaya/cost atas internet yang harus dikeluarkan tiap usaha UMKM dalam pelayanan pajak secara daring maupun $e$-filling.

Berdasarkan Peraturan Pemerintah Nomor 23 tahun 2018 mengenai pajak penghasilan atas perolehan penghasilan dari peredaran bruto atas usahanya, menjelaskan batas waktu pengenaan tarif untuk wajib pajak orang pribadi yaitu sampai tujuh tahun, badan berbentuk CV sampai empat tahun, sedangkan wajib pajak berbentuk PT sampai tiga tahun. Setelah batas waktu yang telah ditentukan, wajib pajak akan dikenakan tarif pajak penghasilan 17 (progresif) atas pajak penghasilannya. Namun yang diharapkan pemerintah dengan adanya batas waktu pengenaan tarif yang dilakukan pemerintah tersebut untuk wajib pajak usaha Mikro dan kecil menengah (UMKM) dapat mandiri dan segera menjalankan pembukuan atas laporan keuangannya atas pajak penghasilannya. Menurut Tjahjono (2005) dalam Hestanto (2018) menjelaskan bahwa sanksi perpajakan adalah alat bagi pemerintah dalam mencegah dan mengatasi wajib pajak yang telah melanggar kewajiban perpajakannya, dan menjadi jaminan atas kepatuhan dariwajib pajak tersebut. Setelah adanya perpanjangan masa pelaporan yang telah diberikan oleh pemerintah, dan wajib pajak UMKM tetap tidak mau menjalankan kewajiban perpajakannya maka wajib pajak tetap diberikan sanksi perpajakan Menurut Direktorat Jenderal Pajak (2019) menjelaskan bahwa sanksi perpajakan ada dua yaitu sanksi administrasi denda,bunga atau kenaikan yaitu wajib menyetor PPh Final sebesar 0,5\% dari tarif PP No 23/2018 dan sanksi administrasi berupa bunga $2 \%$ perbulan (maksimal 24 bulan), dari biaya yang terlambat atas pembayaran $\mathrm{PPh}$ Final UMKM dan denda Rp. 100.000,00 atas keterlambatan tersebut sampai sanksi pidana penjara atau kurungan atas ketidakpatuhan dari wajib pajak tersebut. Penelitian yang dilakukan Imaniati (2016) menjelaskan bahwa sanksi perpajakan berpengaruh positif dan signifikan terhadap kepatuhan wajib pajak Usaha Mikro Kecil Menengah (UMKM) di kotaYogyakarta.Menurut Asmarani (2020) menjelaskan bahwa kepatuhan wajib pajak adalah suatu faktor terpenting dalam penerimaan pajak negara yang didukung dengan kesadaran dari tiap wajib pajak sendiri dari menghitung, melaporkan dan menyetorkan pajaknya secara mandiri (menjalankan kewajiban perpajakannya) berdasarkan sistem self assessment system. Ada dua jenis kepatuhan wajib pajak diantaranya kepatuhan wajib pajak UMKM secara formal dan kepatuhan secara material,kepatuhan wajib pajak UMKM secara formal terjadi saat wajib pajak UMKM telah memenuhi kewajiban perpajakannya secara formal sesuai dengan ketentuan perpajakan seperti melaporkan omset penghasilannya melalui surat pemberitahuan (SPT). Sedangkan kepatuhan wajib pajak UMKM secara material terjadi saat wajib pajak UMKM telah memenuhi kewajiban perpajakannya secara material dan formal sekaligus, sesuai dengan ketentuan perpajakan seperti mengisi SPT dengan nominal yang benar dan tepat sesuai dengan seharusnya.

Berdasarkan data Direktorat Jenderal Pajak (2018), menjelaskan tingkat pertumbuhan penerimaan pajak dari kepatuhan wajib pajak secara material di tahun 2012- 2018 mengalami penurunan di tahun 2012-2017 dari 12,54\% menjadi 4,07\%, dan kemudian mengalami kenaikan secara signifikan di tahun 2018 sebesar 14,10\%. Hal itu menjelaskan bahwa tingkat kepatuhan wajib pajak secara material untuk UMKM tergolong rendah sebelumnya, dan masih banyak UMKM yang belum menjalankan kewajiban perpajakannya. Sedangkan kepatuhan wajib pajak secara formal, menunjukkan data bahwa jumlah wajib pajak yang telah melaporkan omsetnya dengan $e$-SPT di tahun 2016 sebanyak 592.282, di tahun 2017 sebanyak 670.623 dan tahun 2018sebanyak723.290.Dariduadatatersebutbaiksecara materialdanformal,menjelaskanbahwawajib pajak mengalami kenaikan dalam tingkat kepatuhan pajaknya. Dengan adanya Covid-19, apakah wajib pajak pelaku usaha UMKM di Surabaya tetap menjalankan kepatuhan pajak secara material dan formal seperti yang terjadi di tahun-tahun sebelumnya, ataukah justru tingkat kepatuhan pajaknya akan semakin menurun dikarenakan pandemi.Teori Planned behavior merupakan sebuah teori yang pertama kali dikemukakan oleh Ajzen(1991),teori ini akan memberikan pengaruh terhadap wajib pajak UMKM baik orang pribadi maupun badan dalam menjalankan kewajiban perpajakannya baik pada saat membayar maupun melaporkan pajak di tengah pandemi Covid-19 mereka dari sisi psikologis. Teori ini juga merupakan perluasan dari Teori Reasoned Action (TRA). Teori atribusi (attribution theory) dikemukakan pertama kali oleh Heider (1958) dan telah dikembangkan oleh 
Kelley (1972). Teori atribusi adalah teori yang memberikan gambaran bahwa setiap orang akan memberikan tafsiran pada kejadian-kejadian tertentu serta akan memiliki kaitan erat dengan pikiran dan perilaku dari setiap orang.Teori ini juga akan menentukan wajib pajak untuk melakukan apa yang wajib pajak lakukan, serta juga dapat memberikan gambaran mengenai bagaimana Direktorat Jenderal Pajak dapat memberi kesan kepada wajib pajak UMKM dari faktor-faktor personal maupun situasional ditengah pandemi Covid-19. Teori ini mampu menjelaskan mengenai faktor-faktor internal apa dan eksternal apa saja yang perlu dilakukan Direktorat Jenderal Pajak dalam meningkatkan kepatuhan wajib pajak UMKM di tengah pandemic Covid-19.

Menurut Undang-Undang Nomor 20 Tahun 2008 dalam Hidayat, KaruniaSaputra (2020) menjelaskan mengenai usaha Mikro, Kecil dan Menengah(UMKM). Usaha mikro, kecil dan menengah memiliki tiga komponen yaitu usaha mikro, usaha kecil dan usaha menengah, secara sekilas sama namun masing-masing komponen memiliki kriteria dan ciri-ciri masing-masing yang membedakannya dari berapa jumlah orang yang menjadi pelaku usahanya, berapa jumlah aset yang dimiliki hingga berapa omset yang dihasilkan dari ketiga usaha tersebut. Menurut Peraturan Pemerintah Nomor 23 tahun 2018 menjelaskan bahwa kriteria wajib pajak Usaha Mikro Kecil Menengah (UMKM) yang dikenakan pajak penghasilan final hanyalah wajib pajak orang pribadi atau badan yang berbentuk baik CV maupun PT yang menjalankan usahanya dan memiliki omset penghasilan dibawah 4,8 Miliarrupiah.Dari semua fenomena, grand theory dan penelitian terdahulu yang telah dipaparkan diatas, maka menjadi dasar untuk melakukan penelitian ini, dikarenakan adanyafenomena Covid-19 di tahun 2020 telah mengguncang berbagai segi kehidupan terutama Usaha Mikro Kecil Menengah di Surabaya sebagai penopang perkembangan perekonomian Indonesia selamaini. Pemerintah telah membuat berbagai kebijakan ditengah pandemic ini dari insentif PMK86/2020,penurunan tariff hingg a0\%, pelayanan fiskus yang sepenuhnya melalui daring/online, batas waktu PP 23/2018 bagi UMKM hingga sanksi perpajakan menjadi penentu keberhasilan kepatuhan pajak bagi UMKM Surabaya menjadi penelitian yang menarik dibandingkan penelitian sebelumnya.

\section{Teori Planned PlannedBehavior)}

Teori Planed behavior (Theory of Planned Behavior) merupakan sebuah teori yang pertama kali dikemukakan oleh Ajzen (1991). Menurut Ajzen (1991) dalam Nugraheni dan Purwanto (2015) menjelaskan mengenai bagaimana manusia berperilaku dan bertindak. Berhubungan dengan pajak itu sendiri,teori ini akan memberikan pengaruh terhadap wajib pajak UMKM baik orang pribadi maupun badan dalam menjalankan kewajiban perpajakannya baik pada saat membayar maupun melaporkan pajak di tengah pandemi Covid-19 mereka dari sisi psikologis. Teori ini juga merupakan perluasan dari Teori Reasoned Action (TRA) yang sama-sama dikemukakan oleh Ajzen dan Fishbein (1975), dimana menjelaskan mengenai perubahan perilaku dari wajib pajak menjadi patuh yang berasal dari niat, perilaku dan norma-norma sosial.

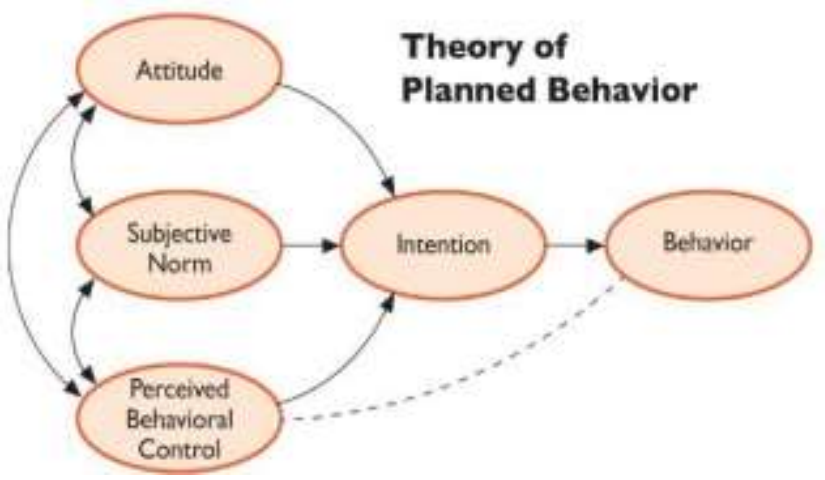

Gambar 1 Teori Planned Behavior

Sumber: Ajzen (1991) dalam Nugraheni dan Purwanto (2015)

Dilihat dari gambar 1 mengenai Teori Planned Behavior, menjelaskan bahwa tiga bagian penting dari kepatuhan yaitu pertama sikap (attitude), dimana menjelaskan mengenai sikap wajib pajak yang taat pajak atau tidak yang akan menentukan perilakunya dalam menjalankan kepatuhan perpajakan. Kedua norma subjektif (subjective norm) menjelaskan mengenai norma yang akan menghasilkan kesadaran bagi wajib pajak untuk patuh dalam menjalankan kewajibannya. Ketiga persepsi untuk mengkontrol perilaku (Perceived Behavioral Control), dimana menjelaskan kontrol perilaku dari wajib pajak itu sendiri baik didapat dari dalam diri mereka sendiri (internal) ataupun pihak luar (eksternal) dari wajib pajak tersebut Dari tiga bagian penting tersebut akan menimbulkanniat (intention) yang akan memberikan pengaruh pada wajib pajak untuk patuh (behavior) 
dalam menjalankan kewajibannya sesuai dengan ketentuan aturan perpajakan yang berlaku.

\section{Teori Atribusi (Attribution Theory)}

Teori atribusi (attribution theory) dikemukakan pertama kali oleh Heider (1958) dan telah dikembangkan oleh Kelley (1972). Menurut Heider (1958) dalam Nugraheni dan Purwanto (2015) menjelaskan bahwa teori atribusi adalah teori yang memberikan gambaran bahwa setiap orang akan memberikan tafsiran pada kejadian-kejadian tertentu, serta akan memiliki kaitan erat dengan pikiran dan perilaku dari setiap orang.Teori atribusi juga akan menentukan wajib pajak untuk melakukan apa yang wajib pajak lakukan, serta juga dapat memberikan gambaran mengenai bagaimana Direktorat Jenderal Pajak dapat member kesan kepada wajib pajak UMKM dari faktor-faktor personal maupun situasional ditengah pandemi Covid-19. Ada tiga tahapan didalamnya, yaitu pertama perilaku wajib pajak UMKM di tengah Pandemi Covid-19 apakah menjadi lebih patuh atau tidak, kedua menentukan apakah wajib pajak melakukan ketidak patuhan karena kesengajaan atau tidak, namun dikarenakan terpaksa tidak dapat membayar karena penurunan ekonomi atau kebangkrutan pada saat pandemi Covid-19, dan terakhir mengelompokkan motivasi yang perlu dilakukan untuk menentukan perilaku wajib pajak yang patuh baik secara internal (dibawah kesadaran wajib pajak) maupun eksternal (lingkungan sekitar).Teori atribusi ini cocok dalam penelitian ini dikarenakan teori ini mampu menjelaskan mengenai faktor-faktor internal apa dan eksternal apa saja yang perlu dilakukan Direktorat Jenderal Pajak dalam meningkatkan kepatuhan wajib pajak UMKM di tengah pandemi Covid-19. Persepsi dalam diri wajib pajak (internal) sendiri dan kesan dari lingkungan (direktorat jenderal pajak) akan mempengaruhi penilaian wajib pajak mengenai pentingnya menjalankan kewajiban perpajakan, kemudian menciptakan kepatuhan bagi wajib pajak UMKM itu sendiri.

\section{Pengaruh Sosialisasi Insentif PMK 86/2020 terhadap Kepatuhan Wajib Pajak UMKM}

Menurut Sudrajat (2015:194), sosialisasi perpajakan adalah upaya yang harus dilakukan oleh pemerintah dalam memberikan informasi kepada wajib pajak, mengenai peraturan perpajakan tertentu agar wajib pajak baik dapat memahami mengenai perpajakan. Sosialisasi perpajakan mengenai insentif PMK 86/2020 memiki peran penting dalam meningkatkan kepatuhan bagi wajib pajak di tengah pandemi Covid-19, agar wajib pajak dapat memahami dan memanfaatkan insentif PMK 86/2020 yang diberikan olehpemerintah.Berdasarkan dari hasil penelitian terdahulu yang dilakukan oleh dilakukan oleh Putri dan Iqbal (2018), Putri dan Nurhassanah (2019) dan Adi (2018) mendapatkan hasil penelitian yang sama-sama menunjukkan bahwa sosialisasi pajak memiliki pengaruh positif dan signifikan terhadap kepatuhan wajib pajak dari pelaku Usaha Kecil Menengah (UKM). Teori planned behavior berkaitan erat dengan kepatuhan bagi wajib pajak dalam menjalankan kewajiban perpajakan (behavioral) melalui niat dan norma subjektif, namun dua komponen tersebut tidak serta merta akan memunculkan pemenuhan kewajiban perpajakan namun harus didukung juga dari tindakan-tindakan eksternal (perceived behavior control) dari Direktorat Jenderal Pajak dalam memberikan hak bagi wajib pajak itu sendiri ditengah pandemi Covid-19 dalam hal mensosialisasikan kebijakan perpajakan baru yaitu insentif PMK 86/2020 yang akan membantu wajib pajak dalam meningkatkan kepatuhan pajak sesuai dengan teori plannedbehaviorkontrol akan memperkuat hipotesis pertama dalam penelitian ini. Berdasarkan penjelasan diatas, maka hipotesis pertama yang digunakan dalam penelitian ini yaitu:

\section{H1: Sosialisasi Insentif PMK 86/2020 berpengaruh} terhadap kepatuhan wajib pajak UMKM.

\section{Pengaruh Tarif Pajak terhadap Kepatuhan Wajib Pajak UMKM}

Menurut Direktorat Jenderal Pajak dalam Boby (2019) menjelaskan bahwa tarif pajak adalah nilai yang menjadi dasar pengenaan pajak dan menjadi penentu pajak yang harus dibayar oleh wajib pajak dan dinyatakan dalam persentase tertentu. Tarif pajak yang telah ditetapkan oleh Direktorat Jenderal Pajak selama ini yang dikenakan untuk Usaha Mikro Kecil Menengah berubah-rubah sesuai dengan kondisi saat ini. Perubahan tarif dari PP 46/2013 sebesar 1\% menjadi tarif PP 23/2018 sebesar 0,5\%, dan tarif khusus di tengah pandemi Covid-19 sebesar 0\%. Penelitian yang dilakukan oleh Oktaviani dan Adellina (2016), Rusdiyanto (2017) dan Rachmawati,dkk (2018) mendapatkan hasil penelitian yang sama-sama menunjukkan bahwa tariff pajak memiliki pengaruh positif dan signifikan terhadap kepatuhanwajibpajak.Teori atribusi memiliki andil dalam penentuan tarif pajak yang harus dibayar oleh 
wajib pajak itu sendiri,berarti bahwa semakin wajib pajak memiliki hak kewajiban bagi suatu negara maka semakin besar pula pajak yang harus dibayarkan kepada pemerintah. Pemerintah harus menetapkan beban pajak yang harus dibayar UMKM sesuai dengan kepentingan wajib pajak, selain itu pemerintah juga harus melihat besarnya penghasilan yang dihasilkan oleh wajib pajak (objektif) dan besarnya kebutuhan material yang harus dipenuhi oleh wajib pajak UMKM (subjektif) di tengah pandemi Covid19. Hal itu dilakukan agar tidak memberatkan bagi wajib pajak UMKM,oleh karena itu pemerintah terus menerus menurunkan tariff pajak UMKM dari PP 46/2013 sebesar $1 \%$ menjadi PP 23/2018 sebesar 0,5\%, hingga terbaru PMK 44/2020 atau PMK 86/2020 sebesar 0\% ditengah pandemic Covid-19 sesuai dengan teori atribusi ini akan memperkuat hipotesis kedua dalam penelitian ini. Berdasarkan penjelasan diatas, maka hipotesis kedua yang digunakan dalam penelitian ini yaitu:

\section{H2: Tarif Pajak berpengaruh terhadap kepatuhan wajib pajak UMKM.}

\section{Pengaruh Pelayanan Fiskus terhadap Kepatuhan Wajib Pajak UMKM}

Pemerintah selama ini telah menjalankan layanan perpajakan baik secara tatap muka maupun daring/online melalui pelayanan e-filling pajak dengan adanya layanan ini pelaporan bagi wajib pajak baik SPT Tahunan (1770, 1770 SS, 1770 S) untuk wajib pajak orang pribadi, dan SPT 1771 untuk badan dapat dilakukan secara online melalui website dari Dirjen pajak, sehingga memudahkan bagi wajib pajak dalam menjalankan kewajiban perpajakannya selama ini. Ditengah pandemi Covid-19 ini, pelayanan fiskus berubah sepenuhnya menjadi pelayanan berbasis $100 \%$ daring/online. Upaya dari DJP tetap diperlukan dalam mempertahankan bahkan meningkatkan kualitas pelayanan pajak bagi UMKM, secara $100 \%$ daring ditengah pandemi yang berguna untuk memberikan kesadaran pada wajib pajak untuk tetap menjalankan kewajiban perpajakannya walaupun di tengahpandemi. Berdasarkan Penelitian terdahulu yang telah dilakukan oleh Tambunan (2016), Asfa dan Meiranto (2017), Rusdiyanto (2017) mendapatkan hasil penelitian yang sama-sama menunjukkan bahwa pelayanan fiskus memiliki pengaruh positif dan signifikan terhadap kepatuhan wajib pajak. Teori atribusi mampu menjelaskan mengenai faktor-faktor internal dan eksternal apa saja yang perlu dilakukan
Direktorat Jenderal Pajak dalam meningkatkan kepatuhan wajib pajak UMKM ditengah pandemi.Persepsi dalam diri wajib pajak (internal) sendiri dan kesan dari lingkungan (direktorat jenderal pajak) akan mempengaruhi penilaian wajib pajak mengenai pentingnya menjalankan kewajiban perpajakan, melalui pelayanan fiskus yang terus dilakukan Direktorat Jenderal Pajak kepada wajib pajak UMKM selama ini kemudian menciptakan kepatuhan bagi wajib pajak UMKM itu sendiri, sehingga teori atribusi ini akan memperkuat hipotesis ketiga dalam penelitian ini. Berdasarkan penjelasan diatas,maka hipotesis ketiga yang digunakan dalam penelitian ini yaitu:

\section{H3: Pelayanan Fiskus berpengaruh terhadap kepatuhan wajib pajak UMKM.}

\section{Pengaruh Batas Waktu PP 23/2018 terhadap Kepatuhan Wajib Pajak UMKM}

Menurut Direktorat Jenderal Pajak (2018), batas waktu dalam pengenaan tarif adalah batas waktu bagi wajib pajak dalam jangka waktu tertentu untuk memperoleh fasilitas pajak penghasilan final terhadap omset penghasilannya. Berdasarkan Peraturan Pemerintah Nomor 23 Tahun 2018 menjelaskan bahwa batas waktu mengenai tarif untuk wajib pajak UMKM sebesar $0,5 \%$ memiliki batas waktu tertentu. Batas waktu tertentu tersebut diatur pemerintah dimana wajib pajak UMKM orang pribadi memiliki batas waktu sampai dengan tujuh tahun, badan berbentuk $\mathrm{CV}$ atau Firma atau koperasi batas waktunya sampai dengan empat tahun, dan untuk badan berbentuk PT sampai dengan tigatahun.Dari batas waktu tersebut pemerintah telah memberikan kemudahan dalam menjalankan kewajiban perpajakannya bagi wajib pajak untuk segera menyelenggarakan pembukuan. Berdasarkan penelitian terdahulu yang telah dilakukan oleh Wahjudi dan Arief Himawan (2014) yang membahas mendapatkan hasil penelitian yang menunjukkanbahwa Usaha Mikro Kecil dan Menengah (UMKM) di Semarang telah menjalankan kewajiban perpajakan menyelenggarakan pembukuan dalam pembayaran pajak secara tepat waktu.Teoriatribusimampu menjelaskan mengenai faktor-faktor internal apa dan eksternal apa saja yang perlu dilakukan Direktorat Jenderal Pajak dalam meningkatkan kepatuhan wajib pajak UMKM di tengah pandemi Covid-19. Persepsi dalam diri wajib pajak (internal) sendiri dan kesan dari lingkungan 
(direktorat jenderal pajak), akan mempengaruhi penilaian wajib pajak mengenai pentingnya menjalankan kewajiban perpajakan yaitu menjalankan kewajiban pembukuan melalui batas waktu yang telah diberikan kepada wajib pajak UMKMselama ini, kemudian akan menciptakan kepatuhan bagi wajib pajak UMKM itu sendiri. Sehingga teori atribusi ini akan memperkuat hipotesis keempat dalam penelitian ini. Berdasarkan penjelasan diatas, maka hipotesis keempat yang digunakan dalam penelitian ini yaitu:

\section{H4: Batas Waktu PP 23/2018 berpengaruh terhadap kepatuhan wajib pajak UMKM.}

\section{Pengaruh Sanksi Perpajakan terhadap Kepatuhan Wajib PajakUMKM}

Menurut Tjahjono (2005) dalam Hestanto (2018) menjelaskan bahwa sanksi perpajakan adalah alat bagi pemerintah dalam mencegah dan mengatasi wajib pajak yang telah melanggar kewajibanperpajakannya, dan menjadi jaminan atas kepatuhan dari wajib pajak tersebut. Setelah adanya perpanjangan masa pelaporan yang telah diberikan oleh pemerintah, dan wajib pajak UMKM tetap tidak mau menjalankan kewajibannya, maka wajib pajak tetap diberikan sanksi perpajakan. Sanksi perpajakan sebagai kunci keberhasilan dari kepatuhan wajib pajak UMKM di tengah pandemi Covid-19 agar wajib pajak UMKM tetap menjalankan kewajiban perpajakan. Sanksi juga sebagai konsekuensi atas pelanggaran kewajiban perpajakan yang telah dilakukan oleh wajib pajak UMKM di tengah pandemi Covid-19. Dengan adanya sanksi perpajakan yang tegas mau tidak mau wajib pajak UMKM tetap menjalankan kewajiban perpajakan baik menyelenggarakan pembukuan, melakukan pelaporan serta pembayaran pajak. Berdasarkan penelitian terdahulu yang telah dilakukan olehSasmita (2015), Muliari dan Setiawan (2015), Oktaviani dan Adellina (2016),Fuadi dan Mangoting (2017) sama-sama mendapatkan hasil penelitian yang menunjukkanbahwa sanksi perpajakan memiliki pengaruh signifikan terhadap peningkatan kepatuhan wajib pajak UMKM. Teori atribusi dapat berhasil apabila prosedur-prosedur yang telah dilakukan oleh Direktorat Jenderal Pajak harus jelas dan tidak memihak pada siapapun terutama dalam hal pengenaan sanksi perpajakan kepada tiap wajib pajak UMKM yang melanggar ketentuan Undang-Undang Perpajakan. Oleh karena itu teori atribusi akan memperkuat hipotesis kelima dalam penelitian ini.
Berdasarkan penjelasan diatas, maka hipotesis kelima yang digunakan dalam penelitian iniyaitu:

H5: Sanksi Perpajakan berpengaruh terhadap kepatuhan wajib pajak UMKM.

\section{Rerangka Konseptual}

Gambar 2 menjelaskan mengenai Rerangka penelitian menunjukkan bahwa dalam penelitian ini menganalisis pengaruh dari Sosialisasi Insentif PMK 86 tahun 2020 (SIP), Tarif Pajak (TP), Pelayanan Fiskus (PF), Batas Waktu PP 23/2018 (BWP), dan Sanksi Perpajakan (SP) akan berpengaruh terhadap Kepatuhan Wajib Pajak UMKM (KWP).

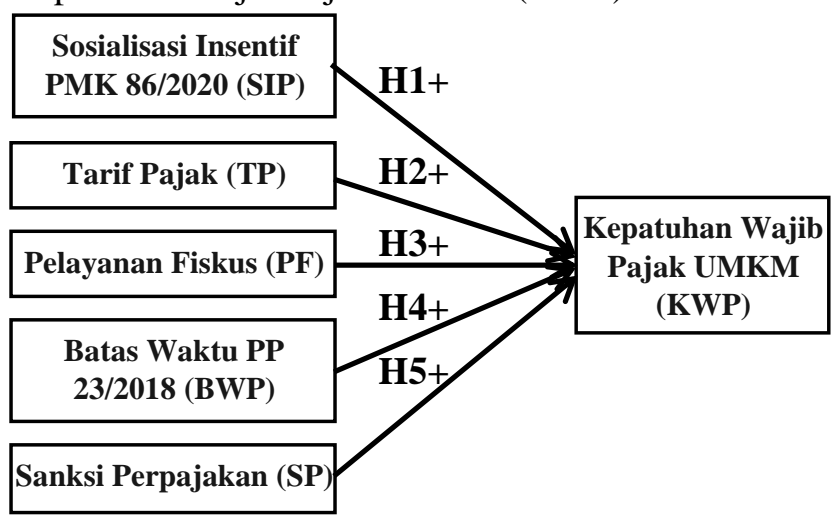

Gambar 2 Rerangka Penelitian.

\section{METODE PENELITIAN}

Desain yang digunakan dalam penelitian ini menggunakan desain penelitian kuantitatif. Pengukuran dari tiap-tiap variabel independen terhadap variabel dependen dilakukan peneliti dengan menggunakan skala likert. Penelitian ini dengan kuisioner berisi pertanyaan-pertanyaan mengenai variabel-variabel independen dan dependen yang terkait dalam penelitian. Sumber data dalam penelitian ini adalah data primer.Data primer merupakan sumber data yang diperoleh secara langsung dari responden yang telah ditentukan sebelumnya oleh peneliti. Sumber data primer dapat diperoleh dalam penelitian ini melalui media kuisioner yang secara langsung akan dibagikan kepada responden melalui google form karena dalam masa pandemic Covid- 19 saat ini. Responden yang dituju dalam penelitian ini yaitu wajib pajak Usaha Mikro Kecil dan Menengah (UMKM) di kota Surabaya.Metode pengumpulan data yang dipilih dalam penelitian ini adalah menggunakan metode survei dengan media pendukung yaitu kuisioner. Metode survei dengan kuisioner ini akan memberikan pertanyaan-pertanyaan kepada partisipan yang menjadi sumber informasi. Partisipan yang terlibat akan diminta untuk mengisi pertanyaan- 
pertanyaan yang telah disediakan dan dapat dikembalikan kepada peneliti jika secara tatap muka. Jawaban dari pertanyaan-pertanyaan tersebut dapat membantu peneliti dalam menganalisis dan mendeskripsikan adanya pengaruh Sosialisasi Insentif PMK 86/2020, Tarif Pajak, Pelayanan Fiskus, Batas Waktu PP 23/2018 dan Sanksi Perpajakan terhadap Kepatuhan Wajib Pajak UMKM.Kuisioner dalam penelitian ini terbagi menjadi dua bagian. Bagian yang pertama yaitu berisikan mengenai pertanyaanpertanyaan umum seputar identitas dari responden yang akan diteliti beserta petunjuk-petunjuk mengenai pengisian data, sedangkan bagian kedua berisikan mengenai instrumen-instrumen penelitian didalamnya berupa pertanyaan- pertanyaan mengenai objek penelitian yang akan diteliti. Pembagian kuisioner ini dilakukan dengan cara menyebarkannya melalui kuisioner berbentuk elektronik ( $e$ - kuisioner) dengan perantara google form yang dapat langsung diisi dengan petunjuk yang ada, dan akan dilakukan pengujian lebih lanjut menggunakan teknik analisis yang tepat untuk menguji hipotesis yang telah dibuat.

\section{Populasi, Sampel dan Teknik Penyampelan}

Populasi penelitian ini adalah Wajib pajak usaha Mikro, Kecil dan Menengah (UMKM) di Surabaya, alasan peneliti menggunakan populasi ini karena keterbatasan waktu dan jangkauan wilayah serta domisili peneliti yang berada di Surabaya sehingga akan mempermudah peneliti dalam menyebarkan kuisioner secara elektronik atau $e$-kuisioner. Data populasi penelitian yang digunakan dalam penelitian ini adalah semua wajib pajak Usaha Mikro Kecil Menengah (UMKM) di kota Surabaya. Penentuan sampel dalam penelitian ini dengan mengggunakan teknik perhitungan sampel dengan teknik Roscoe (1975). Teknik Roscoe (1975) dalam Sugiyono (2015:164) menjadi acuan dalam penelitian ini karena penggunaan teknik Roscoe dilakukan apabila jumlah populasi yang diteliti dalam penelitian tersebut tidak jelas berapa jumlah yang harus diteliti, dan keberadaannya sehingga populasi tersebut tidak dapat diketahui secara pasti. Teknik pengambilan sampel yang digunakan dalam penelitian ini adalah nonprobability sampling dengan teknik convenience sampling. Sampel dalam penelitian ini didapat sebanyak 103 responden. Teknik analisis data dalam penelitian ini menggunakan teknik analisis dengan pengujian regresi linier berganda dengan SPSS Versi 22. Pengujian ini digunakan agar peneliti dapat mengetahui pengaruh dari Sosialisasi Insentif PMK
86/2020, Tarif Pajak, Pelayanan Fiskus, Batas Waktu PP 23/2018 dan Sanksi Perpajakan terhadap Kepatuhan Wajib Pajak UMKM. Beberapa teknik analisis data yang digunakan dalam penelitian ini,diantaranya:uji validitas, reliabilitas, statistik deskriptif, uji asumsi klasik, uji kelayakan model dan uji hipotesis.

\section{HASIL DAN PEMBAHASAN \\ 3.1. Hasil Penelitian Uji Validitas}

Uji validitas digunakan dalam menguji valid atau tidaknya suatu instrumen penelitian dalam suatu kuisioner sebelum kuisioner tersebut disebar kepada responden sebagai partisipan utama. Jika instrumen suatu penelitian diuji dan telah valid, dapat dikatakan bahwa alat ukur penelitian tersebut dapat membantu peneliti dalam mendapatkan informasi yang dibutuhkan.Dari hasil pengujian validitas didapat hasil:

Tabel 1

Uji Validitas

\begin{tabular}{|c|c|c|c|}
\hline $\begin{array}{c}\text { Indikator } \\
\text { Variabel }\end{array}$ & $\begin{array}{c}\text { Nilai } \\
\text { Sig.level } \\
\text { 2(tailed) }\end{array}$ & $\begin{array}{c}\text { Pearson } \\
\text { Correlation }\end{array}$ & $\begin{array}{c}\text { Valid/ } \\
\text { Tidak } \\
\text { Valid }\end{array}$ \\
\hline KWP 1 & 0.000 & 0.923 & Valid \\
\hline KWP 2 & 0.000 & 0.898 & Valid \\
\hline KWP 3 & 0.000 & 0.915 & Valid \\
\hline KWP 4 & 0.000 & 0.858 & Valid \\
\hline SIP 1 & 0.000 & 0.588 & Valid \\
\hline SIP 2 & 0.000 & 0.676 & Valid \\
\hline SIP 3 & 0.000 & 0.769 & Valid \\
\hline SIP 4 & 0.000 & 0.756 & Valid \\
\hline SIP 5 & 0.000 & 0.695 & Valid \\
\hline SIP 6 & 0.000 & 0.580 & Valid \\
\hline SIP 7 & 0.000 & 0.699 & Valid \\
\hline TP 1 & 0.000 & 0.831 & Valid \\
\hline TP 2 & 0.000 & 0.862 & Valid \\
\hline TP 3 & 0.000 & 0.739 & Valid \\
\hline PF 1 & 0.000 & 0.793 & Valid \\
\hline PF 2 & 0.000 & 0.829 & Valid \\
\hline PF 3 & 0.000 & 0.839 & Valid \\
\hline PF4 & 0.000 & 0.839 & Valid \\
\hline BWP 1 & 0.000 & 0.848 & Valid \\
\hline BWP 2 & 0.000 & 0.793 & Valid \\
\hline BWP 3 & 0.000 & 0.733 & Valid \\
\hline BWP 4 & 0.000 & 0.742 & Valid \\
\hline SP 1 & 0.000 & 0.907 & Valid \\
\hline SP 2 & 0.000 & 0.897 & Valid \\
\hline
\end{tabular}




\begin{tabular}{|c|c|c|c|}
\hline $\begin{array}{c}\text { Indikator } \\
\text { Variabel }\end{array}$ & $\begin{array}{c}\text { Nilai } \\
\text { Sig.level } \\
\text { 2(tailed) }\end{array}$ & $\begin{array}{c}\text { Pearson } \\
\text { Correlation }\end{array}$ & $\begin{array}{c}\text { Valid/ } \\
\text { Tidak } \\
\text { Valid }\end{array}$ \\
\hline SP 3 & 0.000 & 0.864 & Valid \\
\hline SP 4 & 0.000 & 0.909 & Valid \\
\hline SP 5 & 0.000 & 0.904 & Valid \\
\hline
\end{tabular}

Sumber: Data diolah (2020).

Berdasarkan tabel 1 mengenai uji validitas dapat disimpulkan bahwa darisemua variabel penelitian yaitu kepatuhan wajib pajak UMKM (KWP), Sosialisasi Insentif PMK 86/2020 (SIP), Tarif Pajak (TP), Pelayanan Fiskus (PF), Batas Waktu PP 23/2018 (BWP), dan Sanksi Perpajakan (SP) di atas terlihat bahwa seluruh nilai sig. pada tiap-tiap indikator terhadap total tiap indicator dari semua variabel adalah kurang dari 0,005 ( $\mathrm{r}$ hitung > $\mathrm{r}$ tabel) yaitu 0.000, sehingga dapat dikatakan bahwa semua data yang didapat merupakan data yangvalid

\section{Uji Reliabilitas}

Uji reliabilitas merupakan metode pengujian yang digunakan untuk menguji jawaban dari partisipan terhadap kuisioner yang merupakan indicator instrument penelitian dari variabel yang diteliti. Suatu instrumen dapat dikatakan reliabel jika menghasilkan jawaban yang sama ketika dilakukan penelitian hanya sekali dan hasil tersebut akan dibandingkan dengan pernyataan.

$$
\text { Tabel } 2
$$

Uji Reliabilitas

\begin{tabular}{||c|c|c|}
\hline Indikator Variabel & $\begin{array}{c}\text { Cronbach } \text { 's } \\
\text { Alpha }\end{array}$ & $\begin{array}{c}\text { Reliabel/Tidak } \\
\text { Reliabel }\end{array}$ \\
\hline $\begin{array}{c}\text { Kepatuhan Wajib } \\
\text { Pajak (KWP) }\end{array}$ & 0.920 & Reliabel \\
\hline $\begin{array}{c}\text { Sosialisasi Insentif Pajak } \\
\text { PMK 86/2020 (SIP) }\end{array}$ & 0.806 & Reliabel \\
\hline $\begin{array}{c}\text { Tarif Pajak } \\
\text { (TP) }\end{array}$ & 0.742 & Reliabel \\
\hline $\begin{array}{c}\text { Pelayanan } \\
\text { Fiskus }\end{array}$ & 0.842 & Reliabel \\
\hline $\begin{array}{c}\text { Batas Waktu PP 23/2018 } \\
\text { (BWP) }\end{array}$ & 0.786 & Reliabel \\
\hline $\begin{array}{c}\text { Sanksi Perpajakan } \\
\text { (SP) }\end{array}$ & 0.938 & Reliabel \\
\hline
\end{tabular}

Sumber: Data diolah (2020)

Dari hasil uji reliabilitas didapat nilai cronbach's alpha tiap variabel baik variabel dependen maupun independen. Variabel dependen yaitu kepatuhan wajib pajak UMKM (KWP) memiliki nilai cronbach's alpha sebesar 0,920 dengan jumlah item sebanyak 4. Sedangkan variabel independen yaitu 1. Sosialisasi Insentif PMK 86/2020 (SIP) memiliki nilai cronbach 'salpha sebesar 0.806 dengan jumlah item sebanyak 7,variabel independen 2. Tarif Pajak (TP) memiliki nilai cronbach's alpha sebesar 0.742 dengan jumlah item sebanyak3, variabel independen 3.Pelayanan Fiskus (PF) memiliki nilai cronbach 'salpha sebesar 0.842 dengan jumlah item 4, variabel independen 4 Batas waktu PP 23/2018 memiliki nilai cronbach 's alpha sebesar 0.786 dengan jumlah item sebanyak 4 dan variabel independen 5. Sanksi Perpajakan (SP) memiliki nilai cronbach's alpha sebesar 0.938 dengan jumlah item sebanyak 5. Berdasarkan semua data dan nilai cronbach 'salpha dari masing-masing variabel bernilai lebih dari (>) 0,70, maka dapat disimpulkan bahwa seluruh data kuisioner dari tiap variabel adalahreliabel.

\section{Uji Statistik Deskriptif}

Uji statistik deksriptif pada penelitian ini digunakan untuk menjelaskan mengenai nilai minimum, maximum, mean dan standard deviation dari 5 variabel independen dan 1 variabel dependen. Nilai-nilai hasil pengujian statistik deskriptif ini disajikan dalam tabel dibawah ini.

Tabel 3

Hasil Uji Statistik Deskriptif

\begin{tabular}{|c|c|c|c|c|c|}
\hline & N & Min & Max & Mean & Std. Deviation \\
\hline KWP & 103 & 1.50 & 5.00 & 4.4709 & 0.67908 \\
\hline SIP & 103 & 1.29 & 5.00 & 4.3444 & 0.66474 \\
\hline TP & 103 & 1.00 & 5.00 & 4.3109 & 0.72557 \\
\hline PF & 103 & 1.25 & 5.00 & 4.1578 & 0.71828 \\
\hline BWP & 103 & 1.00 & 5.00 & 4.1796 & 0.69963 \\
\hline SP & 103 & 1.00 & 5.00 & 4.3340 & 0.78834 \\
\hline $\begin{array}{c}\text { Valid N } \\
\text { (listwise) }\end{array}$ & 103 & & & & \\
\hline \multicolumn{7}{|c|}{ Sumber: Data diolah (2020) } \\
\hline
\end{tabular}

\section{Uji Asumsi Klasik}

Uji Asumsi Klasik digunakan dalam penelitian ini dengan tujuan agar peneliti dapat mengetahui apakah data-data dalam penelitian yang dilakukannya sudah memenuhi asumsi-asumsi klasik dalam penelitian atau tidak.Syarat dari pengujian ini dapat terpenuhi apabila data tersebut telah terdistribusikan secara normal, bebas multikolinearitas serta heterokedastisitas. 


\section{Uji Normalitas}

Uji normalitas adalah suatu uji yang dilakukan dalam penelitian untuk menguji dan menganalisis data dalam penelitian yang digunakan dalam variabel penelitian baik variabel dependen atau independen telah terdistribusi secara normal atau tidak.

Tabel 4

UjiNormalitas.

\begin{tabular}{|c|c|c|c|c|c|}
\hline $\mathbf{N}$ & Normal Parameters & & $\begin{array}{c}\text { Asymp } \\
\text { Sig (2- } \\
\text { tailed) }\end{array}$ & $\begin{array}{c}\text { Terdistr } \\
\text { ibusi } \\
\text { Normal/ } \\
\text { Tidak }\end{array}$ \\
\hline & Mean & $\begin{array}{c}\text { Std. } \\
\text { Deviation }\end{array}$ & $\begin{array}{c}\text { Test } \\
\text { Statistic }\end{array}$ & & \\
\hline 103 & 0.0000000 & 0.36110529 & 0.064 & 0.200 & $\begin{array}{c}\text { Terdistri } \\
\text { busi } \\
\text { Normal }\end{array}$ \\
\hline
\end{tabular}

Sumber: Data diolah (2020)

Dalam penelitian ini menggunakan pengujian normalitas dengan jenis kolmogorov-smirnov, one sample test, berdasarkan data tabel 4 uji normalitas di atas dapat dijelaskan bahwa nilai Asymp. Sig. (2tailed) bernilai 0,200 , nilai itu menunjukkan hasil Assymp. Sig (2-tailed) lebih dari 0,05. Hal tersebut berarti dapat disimpulkan bahwa $\mathrm{HO}$ penelitian diterima dan data residual telah terdistribusi normal.

\section{Uji Heterokedastisitas}

Uji heterokedastisitas dilakukan oleh peneliti dengan tujuan untuk menguji apakah varian dalam variabel yang digunakan dalam penelitian memiliki kesamaan atau tidak.

\section{Tabel 5}

Uji Heterokedastisitas

\begin{tabular}{||c|c|c|}
\hline $\begin{array}{c}\text { Variab } \\
\text { el }\end{array}$ & $\begin{array}{c}\text { Unstandardized } \\
\text { Residual }\end{array}$ & $\begin{array}{c}\text { Terjadi/ Terbebas dari gejala } \\
\text { Heterokedastisitas }\end{array}$ \\
\hline SIP & 0.729 & Tidak Terjadi Heterokedastisitas \\
\hline TP & 0.832 & Tidak Terjadi Heterokedastisitas \\
\hline PF & 0.929 & Tidak Terjadi Heterokedastisitas \\
\hline BWP & 0.884 & Tidak Terjadi Heterokedastisitas \\
\hline SP & 0.740 & Tidak Terjadi Heterokedastisitas \\
\hline \multicolumn{3}{|c|}{ Sumber: Data diolah (2020) }
\end{tabular}

Tabel 5 menjelaskan mengenai Uji heterokedastisitas pada penelitian ini yang menggunakan uji Spearman menunjukkan data sig SIP sebesar 0.729, TP sebesar 0.832, PF sebesar 0.929, BWP sebesar 0.884, SP sebesar 0.740. Berdasarkan data di atas terlihat bahwa nilai sig dari tiap variabel adalah di atas 0,05 yang berarti data terbebas dari gejala heterokedastisitas.

\section{Uji Multikolinearitas}

Uji multikolinearitas dilakukan oleh peneliti memiliki tujuan untuk menilai apakah model regresi yang digunakan dalam penelitian dapat ditemukan adanya korelasi antara satu variabel independen dengan variabel independen lainnya.

\section{Tabel 6}

Uji Multikolinearitas

\begin{tabular}{|c|c|c|c|}
\hline Variabel & Sig & VIF & Multikolinearitas/Tidak \\
\hline SIP & 0.015 & 3.037 & Tidak Terjadi Multikolinearitas \\
\hline TP & 0.007 & 2.710 & Tidak Terjadi Multikolinearitas \\
\hline PF & 0.023 & 3.152 & Tidak Terjadi Multikolinearitas \\
\hline BWP & 0.016 & 3.691 & Tidak Terjadi Multikolinearitas \\
\hline SP & 0.976 & 3.609 & Tidak Terjadi Multikolinearitas \\
\hline \multicolumn{3}{|c}{ Sumber: Data diolah (2020) }
\end{tabular}

Berdasarkan data tabel 6 uji multikolinearitas diatas terlihat bahwa seluruh nilai tolerance adalah di atas 0,1 dan semua VIF di bawah 10, dengan hasil SIP memiliki hasil VIF sebesar 3.037, TP memiliki hasil VIF sebesar 2.710, PF memiliki hasil VIF sebesar 3.152, BWP memiliki hasil VIF sebesar 3.691, dan SP memiliki hasil VIF sebesar 3.609 sehingga dikatakan bahwa data tidak terjadi kolerasi dan terbebas atau tidak terjadi gejala multikolinearitas.

\section{Uji Kelayakan Model}

Uji kelayakan model digunakan sebagai pengukuran ketepatan atas analisis regresi saat nilai aktual diperkirakan, uji kelayakan model dalam penelitian ada dua, diantaranya: uji koefisien Determinasi $\left(\mathrm{R}^{2}\right)$ dan uji Statistik F. Data yang dihasilkan dari pengolahan data:

\section{Uji Koefisien Determinasi $\left(\mathbf{R}^{2}\right)$}

Uji Koefisien Determinasi $\left(\mathrm{R}^{2}\right)$ dilakukan dalam penelitian dengan tujuan agar peneliti dapat mengukur serta mengetahui sejauh apa kemampuan suatu model penelitian dapat menjelaskan variasi dari variabel penelitian yaitu dari variabel dependen.

Tabel 7

Uji Koefisien Determinasi $\left(\mathrm{R}^{2}\right)$.

\begin{tabular}{|c|c|c|c|c|c|}
\hline $\begin{array}{c}\text { Mode } \\
\mathbf{l}\end{array}$ & $\mathbf{R}$ & $\begin{array}{c}\boldsymbol{R} \\
\text { Square }\end{array}$ & $\begin{array}{c}\text { Adjusted } \\
\boldsymbol{R} \\
\text { Square }\end{array}$ & $\begin{array}{c}\text { Std. Error } \\
\text { of The } \\
\text { Estimate }\end{array}$ & $\begin{array}{l}\text { Durbin- } \\
\text { Watson }\end{array}$ \\
\hline 1 & $0.847^{\mathrm{a}}$ & 0.717 & 0.703 & 0.37030 & 1.852 \\
\hline
\end{tabular}

Sumber: Data diolah (2020)

Berdasarkan data di atas terlihat bahwa nilai adjusted $R$ square adalah 0,717 atau sebesar 70,3\% dan tergolong tinggi dengan standard error sebesar 0.37030. Hal tersebut berarti bahwa variabel 
independen mempengaruhi variable dependen sebesar 70,3\%. Sedangkan sisanya $29.7 \%$ berasal dari variabel lain yang berada di luar penelitian ini. Hasil $R$ square juga tergolong tinggi dan mendekati 1 , maka dapat disimpulkan bahwa variabel-variabel independen dapat menjelaskan variasi dar ivariabel dependen secara luas dan mengandung banyak informasi bagi penelitian tersebut serta semakin kuat hubungan antara variabel independen dengan variabel dependen karena nilainya mencapai 0.847 .

\section{Uji StatistikF}

Uji Statistik F atau uji kelayakan model dilakukan oleh peneliti dalam penelitian agar peneliti dapat menguji serta mengetahui tepat atau tidaknya fungsi dari suatu regresi dalam melakukan pengukuran suatu nilai secara aktual maupun secara statistik.

Tabel 8

Uji Statistik F

ANOVA

\begin{tabular}{|c|c|c|c|c|c|}
\hline Model & $\begin{array}{c}\text { Sum of } \\
\text { Square }\end{array}$ & Df & $\begin{array}{c}\text { Mean } \\
\text { Square }\end{array}$ & F & Sig \\
\hline Regresi & 33.737 & 5 & 6.747 & 49.209 & $0.000^{\mathrm{b}}$ \\
\hline Total & 47.038 & 102 & & & \\
\hline
\end{tabular}

Sumber: Data diolah (2020)

Berdasarkan data di atas terlihat bahwa nilai signifikansi adalah 0,000 itu berarti nilai sig.F yang didapat dari penelitian kurang dari 0,05 . Hal tersebut berarti bahwa model penelitian diterima serta layak digunakan dan variabel independen bersama mempengaruhi variable dependen. Sesuai dengan hasil perhitungan uji $\mathrm{F}$ yang dilakukan dengan bantuan program SPSS di atas, diperoleh nilai signifikansi yang diperoleh adalah sebesar 0,00 , jadi nilai signifikansi ini lebih kecil daripada nilai sign yaitu 0,05 .

\section{Uji Hipotesis}

\section{Persamaan Analisis Linier Berganda}

Berdasarkan hasil uji statistik yang dilakukan dalam penelitian, maka didapat hasil sesuai tabel 9 mengenai uji statistik $\mathrm{t}$ seperti dibawah ini:
Uji t

Tabel 9

Uji t

\begin{tabular}{|c|c|c|c|c|c|}
\hline \multirow{3}{*}{ Model } & \multicolumn{2}{|c|}{$\begin{array}{c}\text { Unstandardized } \\
\text { Coefficients }\end{array}$} & \multicolumn{2}{c|}{$\begin{array}{c}\text { Standardized } \\
\text { Coefficients }\end{array}$} & \\
\cline { 2 - 6 } & $\mathbf{B}$ & Std. Error & Beta & $\mathbf{t}$ & Sig \\
\hline $\begin{array}{c}1 \\
\text { (Constant) }\end{array}$ & 0.561 & 0.255 & & 2.201 & 0.030 \\
\hline SIP & 0.237 & 0.096 & 0.232 & 2.464 & 0.015 \\
\hline TP & 0.229 & 0.083 & 0.244 & 2.747 & 0.007 \\
\hline PF & 0.210 & 0.091 & 0.222 & 2.314 & 0.023 \\
\hline BWP & 0.248 & 0.101 & 0.255 & 2.459 & 0.016 \\
\hline SP & -0.003 & 0.088 & -0.003 & -0.030 & 0.976 \\
\hline \multicolumn{5}{|c|}{ Sumber: Data diolah (2020) } \\
\end{tabular}

Maka persamaan linier berganda ini adalah: $\mathrm{KWP}=0.561+0,237 \mathrm{SIP}+0,229 \mathrm{TP}+0,210 \mathrm{PF}+$

$$
0,248 \text { BWP }-0.003 \mathrm{SP}+\mathrm{e}
$$

Berdasarkan data tabel $9 \mathrm{~d}$ i atas terlihat bahwa:

a. Nilai Sig pada SIP (0.015), TP (0.007), PF (0.023) dan BWP (0.016) kurang dari 0,05 (Sig < 0,05) yang berarti bahwa variabel Sosialisasi Insentif PMK86/2020 (SIP), Tarif Pajak (TP), Pelayanan Fiskus (PF), Batas Waktu PP 23/2018 (BWP) tersebut berpengaruh terhadap Kepatuhan Wajib Pajak UMKM (KWP).

b. Nilai Sig pada SP (0.976) lebih dari 0,05 (Sig > $0,05)$ yang berarti bahwa variabel Sanksi Perpajakan (SP) tersebut tidak berpengaruh terhadap Kepatuhan Wajib Pajak UMKM (KWP).

\subsection{Pembahasan}

Berdasarkan dari hipotesis yang telah ditentukan diawal, kemudian diuji dan dibandingkan dengan hasil yang diharapkan dengan hasil pengujian aktual. Tabel 3.10 dibawah ini menunjukkan dan menyajikan mengenai informasi ringkasan dari hasil hipotesis penelitian dan berikut pembahasannya:

Tabel 10

Ringkasan Hasil Hipotesis Penelitian

\begin{tabular}{|l|c|}
\hline \multicolumn{1}{|c|}{ Hipotesis } & $\begin{array}{l}\text { Hasil Uji } \\
\text { Hipotesis }\end{array}$ \\
\hline $\begin{array}{l}\text { H1=Sosialisasi Insentif PMK 86/2020 } \\
\text { berpengaruh terhadap kepatuhan wajib } \\
\text { pajak UMKM. }\end{array}$ & Diterima \\
\hline $\begin{array}{l}\text { H2= Tarif Pajak berpengaruh terhadap } \\
\text { Kepatuhan Wajib Pajak UMKM. }\end{array}$ & Diterima \\
\hline $\begin{array}{l}\text { H3=Pelayanan Fiskus berpengaruh } \\
\text { terhadap kepatuhan wajib pajak UMKM. }\end{array}$ & Diterima \\
\hline $\begin{array}{l}\text { H4=Batas Waktu PP 23/2018 } \\
\text { berpengaruh terhadap kepatuhan wajib } \\
\text { pajak UMKM. }\end{array}$ & Diterima \\
\hline
\end{tabular}




\begin{tabular}{|c|c|}
\hline Hipotesis & $\begin{array}{l}\text { Hasil Uji } \\
\text { Hipotesis }\end{array}$ \\
\hline $\begin{array}{l}\text { H5=Sanksi Perpajakan berpengaruh } \\
\text { terhadap kepatuhan wajib pajak UMKM. }\end{array}$ & Ditolak \\
\hline
\end{tabular}

Sumber: Data diolah (2020)

\section{Pengaruh Sosialisasi Insentif PMK 86/2020 terhadap Kepatuhan Wajib PajakUMKM}

Hipotesis pertama dalam penelitian ini diterima yaitu sosialisasi insentif PMK 86/2020 berpengaruh terhadap kepatuhan wajib pajak UMKM. Berdasarkan pada pengujian yang telah dilakukan, sosialisasi insentif PMK 86/2020 selama ini yang dilakukan oleh pemerintah ditengah pandemi memberikan pengaruh terhadap kepatuhan wajib pajak UMKM. Pemerintah selama ini telah mengantisipasi dan mensosialisasikan insentif PMK 86/2020 setelah PMK44/2020, karena saat PMK 44/2020 menunjukkan data masih banyak UMKM yang belum mengetahui apa saja yang diperlukan dalam pengajuan sampai memanfaatkan insentif pajak PMK86/2020.

Data Direktorat Jenderal Pajak (2020) menunjukkan sebesar 6,8\% wajib pajak yang memanfaatkan insentif di bulan Mei 2020, dan pemerintah tidak mau hal itu terjadi terus menerus oleh karena itu pemerintah terus mensosialisasikan insentif PMK 86/2020 kepada wajib pajak UMKM sampai saat ini melalui media cetak maupun elektronik. Pemerintah juga berulangkali merubah peraturan mengenai insentif pajak dari PP 23/2018 menjadi PMK 44/2020 dan terakhir PMK 86/2020, serta memperpanjang waktu pemanfaatan insentif dari September menjadi Desember2020. Hasil pengujian ini sesuai dengan teori planned behavior (TPB) yang berkaitan erat dengan kepatuhan bagi wajib pajak dalam menjalankan kewajiban perpajakan (behavioral) melalui niat dan norma subjektif, karena dua komponen yaitu niat dan norma tersebut tidak serta akan memunculkan pemenuhan kewajiban perpajakan, namun harus didukung juga dari tindakantindakan eksternal (perceived behavior control) dari Direktorat Jenderal Pajak dalam memberikan hak bagi wajib pajak itu sendiri ditengah pandemi Covid-19 dalam hal mensosialisasikan kebijakan perpajakan baru yaitu insentif PMK 86/2020 di tengah covid-19 ini, program ini juga terbilang baru dan hanya muncul di tengah pandemi (2020) dibandingkan programprogram insentif pajak lain seperti tax holiday atau tax allowance sehingga pemerintah mensosialisasikan kepada UMKM yang belum mengerti cara memanfaatkannya agar membantu UMKM mengatasi masalah ekonomi di tengah pandemi Covid 19.

Teori ini juga membentuk motivasi bagi wajib pajak itu sendiri untuk patuh dalam menjalankan kewajibannya, selain teori tersebut teori lain yang mendukung penelitian ini yaitu teori atribusi mendukung penelitian ini dengan menjelaskan faktor internal dalam diri wajib pajak itu sendiri mengenai pengetahuan perpajakan yang didapat dalam sosialisasi insentif tersebut yang menjelaskan juga hak dan kewajiban bagi wajib pajak itu sendiri dalam menjalankan kewajibannya. Hasil penelitian terdahulu dari Putri dan Iqbal (2018), Putri dan Nurhassanah (2019), Adi (2018), dan Setiawan (2018) menunjukkan pengaruh positif terjadi ketika terjadi sosialisasi terus menerus atau secara masif terhadap wajib pajak terhadap peraturan baru tersebut. Oleh karena itu sosialisasi insentif pajak secara elektronik yang dilakukan pemerintah sudah sangat masif sehingga banyak UMKM yang mengetahui dan mencari tahu informasi mengenai insentif pajak PMK86/2020 ini serta memanfaatkannya sampai saat ini ditengah pandemi.

Dengan bekal pengetahuan melalui sosialisasi ini, wajib pajak UMKM menyadari kemudahan yang diberikan oleh pemerintah dalam menjalankan kewajibanperpajakan.Kemudahan tersebut berupa pembayaran pajak di tengah pandemi yang sepenuhnya ditanggung oleh pemerintah dengan memanfaatkan insentif PMK 86/2020 atau wajib pajak UMKM tidak perlu membayar pajak sama sekali. Wajib pajak UMKM akhirnya merasa bahwa pemerintah menyadari kesulitan ekonomi yang dirasakan mereka di tengah pandemi ini. Kemudahan dan wujud kepedulian dari pemerintah tersebut akan cenderung otomatis membuat wajib pajak UMKM sadar akan kewajibannya yaitu tetap menjalankan kewajiban perpajakannya dalam melaporkan pajak penghasilannya walaupun ditengah pandemi sekalipun, sehingga sosialisasi insentif PMK 86/2020 ini berpengaruh terhadap kepatuhan wajib pajak UMKM.

\section{Pengaruh Tarif Pajak terhadap Kepatuhan Wajib PajakUMKM}

Hipotesis kedua dalam penelitian ini diterima yaitu tarif pajak berpengaruh terhadap kepatuhan wajib pajak UMKM. Berdasarkan pada pengujian yang telah dilakukan, karena ditengah pandemi ini pemerintah telah menurunkan tarif pajak dari PP 23/2018 sebesar 0,5\% menjadi PMK 86/2020 sebesar 
$0 \%$, dan banyak yang mulai memanfaatkan insentif pajak ditengah pandemic Covid-19 ini seperti yang sudah dijelaskan di sosialisasi insentif PMK 86/2020.

Data menjelaskan bahwa terdapat 84 wajib pajak UMKM yang memanfaatkan insentif pajak PMK 86/2020 dari 103 wajib pajak, itu berarti terdapat $81,6 \%$ wajib pajak UMKM yang memanfaatkan, sedangkan sisanya $18,4 \%$ wajib pajak UMKM tidak memanfaatkan insentif ini. Program ini tergolong program tarif yang ditanggung pemerintah hanya terjadi di tengah Covid-19 dan UMKM cenderung lebih memanfaatkan tariff yang lebih murah yaitu $0 \%$ atau ditanggung pemerintah, dibandingkan tarif lainnya sebesar $0,5 \%$, karena tarif pajak dianggap akan memberatkan bagi UMKM yang lesu akibat terdampakCovid-19.Mereka akan secara otomatis memanfaatkan program tarif yang ditanggung pemerintah, sehingga berpengaruh terhadap kepatuhan pajak di tengah pandemi dengan UMKM melaporkan pajak untuk persyaratan pemanfaatan insentif tersebut. Hasil pengujian penelitian ini juga sesuai dengan teori atribusi memiliki andil dalam penentuan tariff pajak yang harus dibayar oleh wajib pajak itu sendiri itu,berarti bahwa semakin wajib pajak memiliki hak kewajiban bagi suatu negara, maka semakin besar pula pajak yang harus dibayarkan kepada pemerintah. Didalam teori atribusi juga mempengaruhi faktor eksternal dari kepatuhan wajib pajak UMKM berupa pemanfaatan tarif pajak yang lebih murah membuat wajib pajak lebih patuh.

Teori planned behavior juga mendukung penelitian ini melalui niat yang dirasa wajib pajak UMKM dengan tariff yang ditanggung pemerintah (tarif 0\%) sehingga menimbulkan kepatuhan wajib pajak, namun pemerintah belum sepenuhnya memberikan kebijakan untuk mempermudah pemanfaatan tariff tersebut. Pemerintah telah menetapkan beban pajak yang harus dibayar UMKM sesuai dengan kepentingan wajib pajak dalam melindungi diri wajib pajak, selain itu pemerintah juga harus melihat besarnya penghasilan yang dihasilkan oleh wajib pajak (objektif) dan besarnya kebutuhan material yang harus dipenuhi oleh wajib pajak UMKM (subjektif) di tengah pandemic Covid19, karena usaha UMKM membutuhkan bantuan di tengah pandemi dan tidak mempunyai penghasilan untuk membayar pajak. Penelitian terdahulu juga mendukung penelitian ini diantaranya yang yang dilakukan oleh Oktaviani dan Adellina (2016), Rachmawati, dkk (2018), Rusdiyanto (2017), menjelaskan bahwa tarif pajak berpengaruh terhadap kepatuhan wajib pajakUMKM.

\section{Pengaruh Pelayanan Fiskus terhadap Kepatuhan Wajib PajakUMKM}

Hipotesis ketiga dalam penelitian ini diterima yaitu pelayanan fiskus berpengaruh terhadap kepatuhan wajib pajak UMKM. Pelayanan fiskus yang dilakukan pemerintah mendukung wajib pajak dalam melaporkan maupun membayar pajak mereka secara $100 \%$ daring/online ditengah pandemi memberikan pengaruh terhadap kepatuhan wajib pajak UMKM yang sebelumnya secara tatap muka. Wajib pajak UMKM akan mengetahui prosedur, tata cara, dan informasi dalam menjalankan kewajiban perpajakan dengan tetap menjalankan protokol kesehatan. Hasil pengujian ini sesuai dengan teori atribusi yang mampu menjelaskan mengenai faktorfaktor eksternal apa saja yang perlu dilakukan Direktorat Jenderal Pajak berupa peningkatan pelayanan fiskus dalam meningkatkan kepatuhan wajib pajak UMKM di tengah pandemi Covid-19.

Persepsi dalam diri wajib pajak (internal) sendiri dan kesan dari lingkungan (Direktorat Jenderal Pajak) akan mempengaruhi penilaian wajib pajak mengenai pentingnya menjalankan kewajiban perpajakan, melalui pelayanan fiskus yang terus dilakukan secara $100 \%$ online ditengah pandemi. Hasil penelitian ini sejalan dengan penelitian yang telah dilakukan oleh Asfa dan Meiranto (2017), Tambunan (2016), Rusdiyanto (2017),dan Setiawan (2015) menjelaskan pengaruh pelayanan fiskus terhadap kepatuhan wajib pajak UMKM. Dengan peralihan pelayanan fiskus ini dari tatap muka menjadi $100 \%$ online mendukung wajib pajak UMKM dalam bertanya dan berkonsultasi dalam prosedur pelaporan serta pembayaran pajak mereka dengan tetap menjalankan protokol kesehatan atau social distancing sesuai apa yang dianjurkan pemerintah di tengah pandemi, sehingga wajib pajak UMKM tidak perlu harus ke kantor pajak untuk mendapatkan informasi pajak maupun menjalankan kewajiban perpajakan mereka dengan melaporkan maupun membayar pajak mereka, dan pemerintah perlu meningkatkan serta mempertahankan kinerja pelayanan fiskus yang sangat baik walaupun di tengah pandemi sekalipun.

\section{Pengaruh Batas Waktu PP 23/2018 terhadap Kepatuhan Wajib Pajak UMKM}

Hipotesis keempat dalam penelitian ini diterima yaitu batas Waktu PP 23/2018 berpengaruh terhadap kepatuhan wajib pajak UMKM. Batas waktu PP 
23/2018 yang telah diberikan oleh pemerintah dalam pemanfaatan tarif mempermudah wajib pajak UMKM dalam menjalankan kewajiban perpajakan. Pemerintah telah memberikan batas waktu PP 23/2018 yaitu 7 tahun untuk PT, 4 tahun untuk CV dan 3 tahun untuk orang pribadi untuk mendukung UMKM dalam memberi waktu mereka dalam memahami cara menjalankan kewajiban pembukuan sampai batas waktu yang diberikan. Selama batas waktu yang diberikan juga membuat wajib pajak dapat melakukan perencanaan kedepan dan terlatih untuk menjalankan kewajiban pembukuan dibandingkan sebelumnya, wajib pajak yang dulunya tidak patuh karena faktorfaktor tertentu misalnya ketidaktauan dalam pelaporan maupun pembayaran pajak sekarang lebih patuh dan memahami cara pelaporan melalui SPT maupun pembayaran pajak.

Batas waktu ini juga akan mendorong pelaksanaan pembukuan bagi wajib pajak agar laporan keuangan mereka lebih rapi dibandingkan sebelumnya sehingga memudahkan mereka juga dalam pinjaman kredit investasi di bank, untuk mengembangkan usaha mereka kedepan maupun pelaporan laporan keuangan bagi UMKM sendiri untuk pelaporan pajak yang harus dilakukan UMKM .Mereka dapat belajar lebih banyak sampai batas waktu yang ditetapkan serta mereka dapat memanfaatkan tarif pajak yang diberikan pemerintah. Selain itu di tengah pandemi Covid 19 pemerintah cenderung memberikan relaksasi batas waktu dalam penjalanan kewajiban pajak bagi UMKM itu sendiri misalnya saja realisasi pengalihan dan investasi harta tambahan, relaksasi batas waktu pengajuan permohonan dan upaya hukum.Dengan batas waktu yang diberikan pemerintah tersebut secara otomatis mendorong wajib pajak UMKM lebih patuh lagi dalam menjalankan kewajibannya selama ini.Pengujian ini sesuai dengan teori atribusi yang mampu menjelaskan mengenai faktor-faktor eksternal berupa batas waktu dilakukan Direktorat Jenderal Pajak dalam meningkatkan kepatuhan wajib pajak UMKM di tengah pandemi Covid-19. Dengan adanya batas waktu itu membentuk persepsi dalam diri wajib pajak (internal) sendiri dan kesan dari lingkungan (Direktorat Jenderal Pajak), akan mempengaruhi penilaian wajib pajak mengenai pentingnya menjalankankewajibanperpajakan yaitu menjalankan kewajiban pembukuan melalui batas waktu yang telah diberikan kepada wajib pajak UMKM selama ini, kemudian akan menciptakan kepatuhan bagi wajib pajak UMKM itu sendiri sehingga batas waktu PP
23/2018 memberikan pengaruh bagi kepatuhan wajib pajak UMKM.Berdasarkan penelitian terdahulu yang telah dilakukan oleh Wahjudi dan Arief Himawan (2014) mendukung hasil penelitian ini yang menunjukkan bahwa Usaha Mikro Kecil dan Menengah (UMKM) di Semarang telah menjalankan kewajiban perpajakan menyelenggarakan pembukuan dalam pembayaran pajak secara tepat waktu, dan wajib pajak telah mengetahui besarnya tariff pajak yang berlaku.Hasil penelitian ini menunjukkan batas waktu yang ditetapkan dalam pemanfaatan tariff dan dorongan pemerintah bagi wajib pajak UMKM untuk segera menjalankan kewajiban pembukuan terutama bagi UMKM yang belum paham mengenai cara pembukuan, akan benar-benar membuat wajib pajak UMKM memanfaatkan waktu yang telah diberikan pemerintah dalam PP 23/2018 untuk segera melaksanakan kewajiban perpajakan mereka dengan patuh dan taat di tengah pandemi, sehingga batas waktu PP 23/2018 ini memiliki pengaruh terhadap kepatuhan wajib pajakUMKM.

\section{Pengaruh Sanksi Perpajakan terhadap Kepatuhan Wajib PajakUMKM}

Hipotesis kelima dalam penelitian ini ditolak yaitu sanksi perpajakan tidak berpengaruh terhadap kepatuhan wajib pajak UMKM di tengah pandemic ini.UMKM tidak mampu memenuhi kewajibannya karena kelesuan ekonomi, oleh karena itu pemerintah cenderung melonggar-longgarkan sanksi atau relaksi sanksi bahkan melakukan penghapusan sanksi di tengah pandemi. Menurut artikel dalam DDTC News (2020) menjelaskan bahwa pemerintah telah memberikan berbagai relaksasi administrasi pajak untuk membantu UMKM dalam pandemi Covid 19, serta sanksi administrasi pajak menjadi lebih fleksibel dan itu baik untuk kepatuhan wajib pajak UMKM. Kebijakan ini juga sesuai dengan keputusan Direktorat Jenderal Pajak (DJP) mengenai kebijakan perpajakan sehubungan dengan penyebaran wabah virus corona 2019, misalnya saja penghapusan sanksi atas penyampaian/pelunasan SPT tahunan $\mathrm{PPh}$ orang pribadi ditahun 2019, penghapusan sanksi atas penyampaian SPT masa $\mathrm{PPh}$ pemotongan/ pemungutan untuk masa pajak Februari 2020 serta penghapusan sanksi bagi UMKM itu sendiri di tengah pandemi yang cenderung membuat mereka cenderung tidak takut akan sanksi- sanksi perpajakan di tengah pandemi. Mereka tahu akan sanksi tersebut, tetapi masih banyak wajib pajak UMKM tidak mau memenuhi kewajiban dengan alasan karena pandemi 
Covid 19 kita tidak mampu menjalankan kewajiban perpajakan. Pemerintah juga melakukan pemeriksaan pajak tidak seketat sebelum pandemi ini tidak terjadi dengan maksud pemerintah tidak mungkin menambah beban bagi wajib pajak untuk harus membayar sanksi pajak di tengah pandemi. Walaupun Sanksi perpajakan sebagai konsekuensi terhadap pelanggaran kepatuhan wajib pajak yang tidak patuh dalam menjalankan kewajiban perpajakannya namun tetap dibutuhkan penerapan sanksi tersebut, sehingga wajib pajak tetap patuh dalam pelaporan maupun pembayaran pajak walaupun ditengah pandemi Covid 19.

Pengujian ini sesuai dengan teori atribusi dimana kepatuhan wajib pajak dapat berhasil apabila prosedur-prosedur yang telah dilakukan oleh Direktorat Jenderal Pajak harus jelas dan tidak memihak pada siapapun, terutama dalam hal pengenaan sanksi perpajakan kepada tiap wajib pajak UMKM yang melanggar ketentuan Undang-Undang Perpajakan.Sanksi tersebut tidak boleh dilonggarlonggar kan dan pemeriksaan pajak tetap harus dilakukan sehingga menimbulkan niat dan norma serta perspektif dari wajib pajak seperti yang juga dijelaskan dalam teori Planned behavior (TPB) dan kepatuhan pajak itu terjadi. Penelitian terdahulu yang dilakukan oleh Oktaviani dan Adellina (2016), Sasmita (2015), Muliari dan Setiawan (2015) menunjukkan hasil sanksi perpajakan memiliki pengaruh terhadap kepatuhan wajib pajak UMKM namun dalam penelitian kali ini tidak terjadi. Penelitian yang sesuai dengan hasil penelitian ini adalah penelitian yang dilakukan oleh Bahri dan Diantimala (2018), dan Penelitian yang dilakukan Ermawati dan Alifi (2018) yang sama-sama menjelaskan sanksi pajak tidak berpengaruh terhadap kepatuhan wajib pajak dikarenakan kelonggaran dalam penerapan sanksi perpajakan tersebut. Sanksi perpajakan yang tidak terlalu ketat di masa pandemic serta berbagai relaksasi yang diberikan pemerintah, menyebabkan hasil penelitian yang dilaksanakan di masa pandemi ini menunjukkan hasil bahwa sanksi perpajakan tidak berpengaruh terhadap kepatuhan wajib pajak UMKM. Oleh karena itu pemerintah tetap harus menerapkan sanksi perpajakan dan melakukan pemeriksaan pajak sebagaimana mestinya dan tidak sepenuh-penuhnya melonggarkan atau merelaksasi sanksi tersebut bagi wajib pajak UMKM, walaupun di tengah pandemi Covid 19 sekalipun agar tercipta kepatuhan bagi wajib pajak UMKM itu sendiri di tengahpandemi.

\section{KESIMPULAN}

Berdasarkan hasil pengujian yang telah dilakukan dalam penelitian ini, maka simpulan yang dapat diperoleh yaitu:

a. Sosialisasi insentif PMK 86/2020 berpengaruh terhadap kepatuhan wajib pajak UMKM, karena sosialisasi insentif ini telah dilakukan pemerintah secara masif secara elektronik sampai sekarang di tengah pandemi Covid 19 sehingga memunculkan pengetahuan dan kesadaran bagi wajib pajak UMKM untuk segera memanfaatkan insentif tersebut.

Serta kesadaranakankemudahandankepedulianyangdib erikanpemerintahmengenaikesulitan ekonomi mereka di tengah pandemi ini, dan membuat wajib pajak UMKM untuk tetap menjalankan kewajiban perpajakannya walaupun di tengah pandemisekalipun.

b. Tarif pajak berpengaruh terhadap kepatuhan wajib pajak UMKM, karena program insentif PMK 86/2020 dengan tarif pajak yang ditanggung pemerintah (tarif 0\%) membuat wajib pajak UMKM segera memanfaatkan tariff yang lebih murah dibandingkan tarifsebelumnya sebesar $0,5 \%$. Tarif pajak sebelumnya yang tetap harus dibayar dianggap akan memberatkan bagi UMKM yang lesu akibat terdampak Covid-19. Namun pemerintah belum sepenuhnya memberikan kebijakan untuk mempermudah pemanfaatan tariff tersebut. Pemerintah tetap harus menetapkan beban pajak yang harus dibayar UMKM sesuai dengan kepentingan wajib pajak dalam melindungi diri wajib pajak, selain itu pemerintah juga harus melihat besarnya penghasilan yang dihasilkan oleh wajib pajak (objektif) dan besarnya kebutuhan material yang harus dipenuhi oleh wajib pajak UMKM (subjektif) di tengah pandemic Covid-19 karena usaha UMKM membutuhkan bantuan ditengah pandemi dan tidak mempunyai penghasilan untuk membayarpajak.

c. Pelayanan fiskus berpengaruh terhadap kepatuhan wajib pajak UMKM, karena perubahan layanan dari tatap muka menjadi $100 \%$ daring/online memudahkan wajib pajak UMKM untuk mengetahui prosedur, informasi, tata cara dalam menjalankan kewajiban perpajakannya dengan 
tetap menjalankan protokol kesehatan di tengah pandemi Covid19. Pelayanan ini juga mendukung wajib pajak UMKM dalam bertanya dan berkonsultasi dalam prosedur pelaporan serta pembayaran pajak mereka dengan tetap menjalankan protocol kesehatan atau social distancing esuai apa yang dianjurkan pemerintah, sehingga wajib pajak UMKM tidak perlu harus ke kantor pajak untuk mendapatkan informasi pajak maupun menjalankan kewajiban perpajakanmereka.

d. Batas Waktu PP 23/2018 berpengaruh terhadap kepatuhan wajib pajak UMKM, karena batas waktu PP23/2018 mendukung UMKM untuk memahami cara menjalankan kewajiban pembukuan sampai batas waktu yang diberikan dan mendorong pelaksanaan pembukuan serta pemanfaatan tarif yang ditentukan. Selama batas waktu yang diberikan membuat wajib pajak dapat melakukan perencanaan kedepan dan terlatih untuk menjalankan kewajiban pembukuan dibandingkan sebelumnya, wajib pajak yang dulunya tidak patuh karena faktor-faktor tertentu misalnya ketidaktauan dalam pelaporan maupun pembayaran pajak sekarang lebih patuh dan memahami cara pelaporan melalui SPT, maupun pembayaran pajak. Dengan batas waktu yang diberikan pemerintah tersebut secara otomatis mendorong wajib pajak UMKM lebih patuh lagi dalam menjalankan kewajibannya selamaini.

e. Sanksi perpajakan tidak berpengaruh terhadap kepatuhan wajib pajak UMKM, karena sanksi perpajakan yang tidak terlalu ketat di masa pandemi dan cenderung longgar serta berbagai relaksasi yang diberikan pemerintah menyebabkan hasil penelitian yang dilaksanakan di masa pandemi ini menunjukkan hasil bahwa sanksi perpajakan tidak berpengaruh terhadap kepatuhan wajib pajak, oleh karena itu pemerintah tetap harus menerapkan sanksi perpajakan dan melakukan pemeriksaan pajak sebagaimana mestinya dan tidak sepenuh-penuhnya melonggarkan atau merelaksasi sanksi.

Terdapat beberapa saran yang diberikan, diantaranya:

a. Saran akademis

Penelitian berikutnya diharapkan dapat mengukur dan melakukan uji beda mengenai insentif pajak setelah PMK 86/2020 terhadap kepatuhan wajib pajak UMKM.

b. Saran praktis

1) Direktorat Jenderal Pajak (DJP) sebaiknya tetap lebih massif dalam mensosialisasikan mengenai insentif pajak PMK 86/2020, tetap mempertahankan dan lebih meningkatkan pelayanannya, serta memberikan pelatihan mengenai pelaksanaan pembukuan bagi UMKM baik selama pandemi maupun setelah pandemic ini berakhir.Dikarenakan masih ada UMKM yang belum mengetahui cara memanfaatkan insentif tersebutsampai saat ini dan mereka masih belum mengetahui cara pembukuan yang benar, serta belum memanfaatkan tarif dan kemudahan yang pemerintah di tengah pandemi ini.

2) Direktorat Jenderal Pajak (DJP) sebaiknya tetap harus menerapkan sanksi perpajakan secara tegas dan tidak cenderung longgar serta tetap melakukan pemeriksaan pajak sebagaimana mestinya walaupun ditengah pandemi sekalipun, agar wajib pajak menjadikan kepatuhan pajak menjadi prioritas utama yang harus dipenuhi sebelum menuntut hak mereka.

\section{REFERENSI}

Ananti,Ridha.(2020).SanksiAdministrasipajaklebihfle ksibel,DDTC:Baikuntukkepatuhan WP. Didapat darihttp://www.klinikpajak.co.id/berita+detail/?i $\mathrm{d}=$ berita+pajak+-+sanksi+administrasi+pajak+ jadi+lebih+fleksibel\%2C+ddtc\%3A+baik+untuk + kepatuhan+wp,20November 2020, Pukul12.55.

Asfa, E.R., dan Meiranto, W. (2017). Pengaruh Sanksi Perpajakan, Pelayanan Fiskus, Pengetahuan dan Pemahaman Perpajakan, Kesadaran Perpajakan Terhadap Kepatuhan Wajib Pajak. Diponegoro Journal of Accounting, 6(3), 1-13.

Asmarani,N.G.C(2020).ApaituKepatuhanPajak?.Did apatdarihttps://news.ddtc.co.id/apa-itu-

kepatuhan-pajak-19757, 02 Agustus 2020, Pukul 19.03 WIB.

Ayu, Ida. (2020). Pemanfaatan Insentif Minim, Apa Komentar Anda? Rebut Hadiah Rp1,5 Juta. Didapat dari

https://news.ddtc.co.id/pemanfaatan-insentifminim-apa-komentar-anda-rebut-hadiah-rp15juta-21953, 17 Juli 2020, Pukul 15.45 WIB. 
Badan Pusat Statistik Surabaya. (2016). Hasil Pendaftaran (Listing) Usahal Perusahaan SensusEkonomi 2016. Didapatdari https://surabayakota.bps.go.id/pressrelease/2018 /01/08/47/hasil-pendaftaran--listing--usahaperusahaaan-sensus-ekonomi-2016.html, 02 Agustus 2020, Pukul 18.21WIB.

Bahri,SdanDiantimala,Y.(2018).PengaruhKualitasPel ayananPajak,PemahamanPeraturan

PerpajakanSertaKepatuhanWajibPajak(PadaKan torPajakKPPPratamaKotaBanda Aceh. Jurnal Economy and Business, 4 (2),318-334.

Boby.(2019).IniJenis-

JenisTarifPajakyangPerluDiketahuiWajibPajak, TarifPPhMasuk Mana? Didapat dari https://lifepal.co.id/media/tarif-pajak-dan-jenisjenisnya-yang-berlaku/, 17 Juli 2020, Pukul 17.30WIB.

Dewan Perwakilan Rakyat. (2007). Undang-Undang Republik Indonesia Nomor 28 Tahun 2007TentangKetentuanUmumdanTataCaraPerp ajakan.Jakarta:DewanPerwakilan Rakyat RepublikIndonesia.

. (2008). Undang-Undang Republik Indonesia Nomor 20 tahun 2008 Tentang Usaha Mikro, Kecil dan Menengah. Jakarta: Dewan Perwakilan Rakyat RepublikIndonesia.

.(2013).Undang-Undang KUP dan Peraturan Pelaksanaannya.

Jakarta: Dewan Perwakilan Rakyat Republik Indonesia.

Direktorat Jenderal Pajak. (2018). Laporan Tahunan DJP 2018 Sinergi Menuju Kemandirian Ekonomi Nasional Peningkatan Kesadaran dan Kepatuhan Wajib Pajak UMKM. Jakarta: Direktorat Jenderal Pajak. .(2019).Laporan Kinerja Direktorat Jenderal Pajak 2019. Jakarta: Direktorat JenderalPajak.. (2020). Kebijakan Pajak Ditanggung Pemerintah Sektor UMKM DiperpanjangHingga Desember 2020. Didapat dari https://www.indopremier.com/ipotnews/ newsDetail.pjp?jdl=Kebijakan_Pajak_Ditanggu ng_Pemerintah_Sektor_UMKM Diperpanjang Hingga_Desember_2020\&news_id=121755\&gr oup_news=IPOTNEWS\&news_date $=\&$ taging $\_s$ ubtype $=$ ECONOMICS \&name $=\&$ search $=y \_g e n e$ $\underline{\text { ral\&q=pajak\%20UMKM\&halaman }=1,15}$

Agustus 2020, Pukul 21.05 WIB.
Ernawati, N dan Alifi, Z. (2018). Pengaruh Pengetahuan Perpajakan dan Sanksi Perpajakan Terhadap Kepatuhan Wajib Pajak dengan Religusitas sebagai Variabel Pemoderasi. Jurnal Ekonomi dan Bisnis, 655-662.

Fuadi, A.O dan Mangonting, Y. (2013). Pengaruh Kualitas Pelayanan, Petugas Pajak, Sanksi PerpajakanDanBiayaKepatuhanPajakTerhadapK epatuhanWajibPajakUMKM.Tax \& Accounting Review, 1(1),18-27.

Ghozali, I. (2016). Aplikasi Analisis Multivariate dengan Program IBM SPSS 23 (Edisi ke-8). Semarang: Universitas Diponegoro.

Hardianti,W.M.,danSetyowati,M.S.(2018).Implement asiKebijakanTaxAllowanceDalam Upaya Peningkatan Iklim Investasi pada Sektor Kelautan dan Perikanan. Jurnal Manajemen Pelayanan Publik, 2 (2), 144-158.

Hestanto. (2018). Teori Perpajakan Indonesia: Sanksi Pajak. Didapat dari https://www.hestanto.web.id/sanksi-pajak/, 23 Juni 2020 Pukul 7.37 WIB.

Hidayat, K.S. (2020). Ketahui Pajak dan Tarif PPh buat Кати Pelaku UMKM!.Didapat dari https://www.jurnal.id/id/blog/ketahui-pajak-dantarif-pph-buat-pelaku-umkm/, 6 Januari 2020, Pukul 08.16 WIB.

Imaniati. Z.Z. (2016). Pengaruh Persepsi Wajib Pajak Tentang Penerapan PP No. 46 Tahun 2013, Pemahaman Perpajakan, Dan Sanksi Perpajakan Terhadap Kepatuhan Wajib Pajak Usaha Mikro, Kecil dan Menengah di Kota Yogyakarta. Jurnal Ilmiah Mahasiswa Yogyakarta, 5(2), 1-13.

Kementerian Pendidikan dan Kebudayaan (2016), Kamus Besar Bahasa Indonesia (KBBI) Online. Didapat dari https://kbbi.web.id/patuh, 15 Agustus 2020, Pukul 05.21 WIB.

Ketua Asosiasi UMKM Indonesia. (2018). Torehan Prestasi Pajak UMKM Sebelum Minta Tarif PPh $0 \%$ Didapat dari https://www.pajakku.com/read/5d104ee7bbac51 76532c196b/Torehan-Prestasi-Pajak-UMKMSebelum-Minta-Tarif-PPh-0\%, 05 Juli 2020, Pukul 09.16WIB.

Khairiyah, Y.R., dan Akhmadi, M.H. (2019). Studi Kualitatif: Dampak Kebijakan Insentif Pajak Usaha Kecil dan Menengah Terhadap Kepatuhan Pajak dan PenerimaanNegara. Jurnal Manajemen Keuangan Publik,36-45. 
Kurniasi, D., dan Halimatusyadiah (2017). Pengaruh Sosialisasi Perpajakan, Pemahaman, Kemudahan dan Manfaat Yang Dirasakan Wajib Pajak UMKM Terhadap Kepatuhan Memiliki NPWP (Study pada Wajib Pajak UMKM di Kota Bengkulu). Jurnal Akuntansi Universitas Bengkulu, 8(2), 101-110.

Lazuardini, dkk. (2018). Pengaruh Pemahaman Peraturan Perpajakan, Tarif Pajak Dan Sanksi Pajak Terhadap Kepatuhan Wajib Pajak UMKM (Studi Pada Wajib Pajak Orang Pribadi Yang Terdaftar di KPP Pratama Malang Selatan).Jurnal Riset Manajemen Fakultas Ekonomi Unisma, 1-10.

Mardiasmo.(2015). Perpajakan Edisi Terbaru 2015. Yogyakarta: Andi.

Menteri Keuangan. (2000). Keputusan Menteri Keuangan No.544/KMK/04/2000 Tentang Kriteria Wajib Pajak Yang Dapat Diberikan Pengembalian Pendahuluan Kelebihan Pembayaran Pajak. Jakarta: Kementerian Keuangan Republik Indonesia. .(2015).Peraturan Menteri Keuangan Nomor 234/PMK.01/2015 Tentang Organisasi dan Tata Kerja Kementerian Keuangan. Jakarta: Kementerian Keuangan RepublikIndonesia. (2020). Peraturan Menteri Keuangan Nomor 44/PMK.03/2020 Tentang Insentif Pajak Untuk Wajib Pajak Terdampak Pandemi Corona VirusDisease 2019. Jakarta: Kementerian Keuangan RepublikIndonesia.

(2020). Peraturan Menteri Keuangan Nomor 86/PMK.03/2020 Tentang Insentif Pajak Untuk Wajib Pajak Terdampak Pandemi Corona VirusDisease 2019. Jakarta: Kementerian Keuangan RepublikIndonesia.

Nugraheni, A.D., Dan Purwanto, A. (2015). FaktorFaktor Yang Mempengaruhi Kepatuhan Wajib Pajak Orang Pribadi (Studi Empiris Pada Wajib Pajak Di Kota Magelang. Diponegoro Journal of Accounting, 4(3), 568-581.

Oktaviani, R.M., dan Adellina, S. (2016). Kepatuhan Wajib Pajak UKM. Jurnal Mahasiswa Akuntansi, Keuangan dan Perbankan, 5(2), 136145.

Presiden Indonesia. (2013). Peraturan Pemerintah Republik Indonesia Nomor 46 Tahun 2013 Tentang Pajak Penghasilan atas Penghasilan dari Usaha yang Diterima atau Diperoleh Wajib Pajak yang Memiliki Peredaran Bruto Tertentu. Jakarta: Presiden Republik Indonesia.
Presiden Indonesia. (2018). Peraturan Pemerintah Republik Indonesia Nomor 23 Tahun 2018 Tentang Pajak Penghasilan atas Penghasilan dari Usaha yang Diterima atau Diperoleh Wajib Pajak yang Memiliki Peredaran Bruto Tertentu. Jakarta: Presiden RepublikIndonesia.

Putri, N.J.P. dan Iqbal, S.(2019). Analisis Kepatuhan Wajib Pajak UMKM Terkait Pemberian Insentif Pajak dalam PP Nomor 23 Tahun 2018.Jurnal Ilmiah Akuntansi Universitas Brawijaya, 1-13.

Redaksi DDTC News. (2020). Hadapi Covid-19, DJP Beri Berbagai Relaksasi Administrasi Pajak. Didapat dari https://news.ddtc.co.id/hadapicovid-19-djp-beri-berbagai- relaksasiadministrasi-pajak-20388, 20 November 2020, Pukul11.55.

Rusdiyanto, I. (2017). Analisis Pengaruh Sosialisasi, Tarif Pajak, Pelayanan, Dan Keadilan Terhadap Kepatuhan Wajib Pajak Orang Pribadi Atas Peraturan Pemerintah Nomor 46 Tahun 2013.Jakarta: Universitas Esa Unggul.

Setiawan,A.M.(2018).PengaruhSosialisasiPajak,Kesa daranWajibPajakdanperspesiWajib Pajak Mengenai Peraturan Pemerintah Nomor 46 Tahun 2013 Tentang Pajak Penghasilan Final UMKM Terhadap Kepatuhan Wajib Pajak (Studi Kasus Pada Wajib Pajak UMKM Di Kabupaten Bantul.Yogyakarta. Jurnal Riset Universitas Muhammadiyah Yogyakarta,1-21.

Setiawan, E.Y. (2015). Pengaruh Kesadaran Wajib Pajak, Pelayanan Fiskus Dan Sanksi Perpajakan Terhadap Kepatuhan Wajib Pajak UMKM Dalam Pelaporan Kewajiban Perpajakan (Studi Kasus pada Wajib Pajak UMKM yang Terdaftar di KPP Pratama Blitar. Blitar: Universitas Islam Negeri Maulana Malik Ibrahim.

Sudrahat, A.D. (2015). Pemanfaatan Teknologi Informasi, Sosialisasi Pajak, Pengetahuan Perpajakan,danKepatuhanPajak.JurnalRisetAku ntansidanPerpajakan,2(2),1-194.

Sugiyono. (2015). Metode Penelitian Kuantitatif, Kualitatif dan $R \& D$. Bandung: Alfabeta. (2017). Metode Penelitian Kuantitatif, Kualitatif dan $R \& D$. Bandung: Alfabeta. 